\title{
Future emissions from shipping and petroleum activities in the Arctic
}

\author{
G. P. Peters ${ }^{1}$, T. B. Nilssen ${ }^{2}$, L. Lindholt ${ }^{3}$, M. S. Eide ${ }^{2}$, S. Glomsrød ${ }^{1,3}$, L. I. Eide ${ }^{2}$, and J. S. Fuglestvedt ${ }^{1}$ \\ ${ }^{1}$ Center for International Climate and Environmental Research - Oslo (CICERO), PB 1129 Blindern, 0318 Oslo, Norway \\ ${ }^{2}$ Det Norske Veritas, Veritasveien 1, 1322 Høvik, Norway \\ ${ }^{3}$ Statistics Norway, Postboks 8131 Dep, 0033 Oslo, Norway
}

Received: 20 December 2010 - Published in Atmos. Chem. Phys. Discuss.: 9 February 2011

Revised: 16 May 2011 - Accepted: 24 May 2011 - Published: 6 June 2011

\begin{abstract}
The Arctic sea-ice is retreating faster than predicted by climate models and could become ice free during summer this century. The reduced sea-ice extent may effectively "unlock" the Arctic Ocean to increased human activities such as transit shipping and expanded oil and gas production. Travel time between Europe and the north Pacific Region can be reduced by up to $50 \%$ with low sea-ice levels and the use of this route could increase substantially as the sea-ice retreats. Oil and gas activities already occur in the Arctic region and given the large undiscovered petroleum resources increased activity could be expected with reduced sea-ice. We use a bottom-up shipping model and a detailed global energy market model to construct emission inventories of Arctic shipping and petroleum activities in 2030 and 2050 given estimated sea-ice extents. The emission inventories are on a $1 \times 1$ degree grid and cover both short-lived components $\left(\mathrm{SO}_{2}, \mathrm{NO}_{\mathrm{x}}, \mathrm{CO}, \mathrm{NMVOC}, \mathrm{BC}, \mathrm{OC}\right)$ and the long-lived greenhouse gases $\left(\mathrm{CO}_{2}, \mathrm{CH}_{4}, \mathrm{~N}_{2} \mathrm{O}\right)$. We find rapid growth in transit shipping due to increased profitability with the shorter transit times compensating for increased costs in traversing areas of sea-ice. Oil and gas production remains relatively stable leading to reduced emissions from emission factor improvements. The location of oil and gas production moves into locations requiring more ship transport relative to pipeline transport, leading to rapid emissions growth from oil and gas transport via ship. Our emission inventories for the Arctic region will be used as input into chemical transport, radiative transfer, and climate models to quantify the role of Arctic activities in climate change compared to similar emissions occurring outside of the Arctic region.
\end{abstract}

Correspondence to: G. P. Peters

(glen.peters@cicero.uio.no)

\section{Introduction}

The Arctic is now experiencing some of the most rapid climate changes on earth. After 2000 years of Arctic cooling, the trend was reversed in the 20th century (Kaufman et al., 2009) with temperatures now rising at approximately twice the rate of the rest of the world with an acceleration of these trends projected in the coming century (ACIA, 2005; IPCC, 2007a). Melting glaciers, reductions in extent and thickness of sea-ice, thawing permafrost and rising sea level are indications of a recent warming in the region (Serreze et al., 2007). Observations over the past 50 years show a decline in Arctic sea-ice extent throughout the year, with the most prominent retreat in summer (Serreze et al., 2007). Some analysts have suggested that the Arctic may be ice free in September as early as 2030 (Wang and Overland, 2009), though others suggested 2066-2085 (Boé et al., 2009). The melting of Arctic sea-ice will effectively unlock the Arctic Ocean, leaving it increasingly open to human activity - particularly oil and gas extraction and shipping.

The potential increase in Arctic activities and emissions will not only have an impact on the global climate, but may also impact on regional temperature trends. Several studies have shown that the forcing and temperature response can be dependent on the location of emissions (e.g., Berntsen et al., 2006; Shindell and Faluvegi, 2009; Hansen et al., 2005), but the sensitivity of the Arctic to regional emissions is not well known. Short-lived components are found to be relatively important for the Arctic and could explain some of the recent warming compared to the global average (Quinn et al., 2008; Shindell and Faluvegi, 2009; Hansen et al., 2005). Both emissions occurring within the Arctic and those transported from outside the Arctic are found to be important (Quinn et al., 2008) and emissions at mid-latitudes can also cause changes in the meridional transport of heat to the

Published by Copernicus Publications on behalf of the European Geosciences Union. 
Arctic (Shindell and Faluvegi, 2009). Mechanisms such as black carbon deposition on snow or ice could also increase local warming trends through a decrease in the snow and ice albedo (ACIA, 2005; Hansen and Nazarenko, 2004; Flanner et al., 2007; Rypdal et al., 2009). To facilitate future climate impact assessments of activities in the Arctic it is necessary to produce specific emission inventories for the Arctic region.

Increased melting of the Arctic sea-ice may also open new possibilities for shipping routes and extended use of existing routes (Paxian et al., 2010; Corbett et al., 2010; Khon et al., 2010). The seaborne cargo along the Northern Sea Route (NSR) has previously been very limited (Paxian et al., 2010; PAME, 2009) and the reported ship emissions low (Paxian et al., 2010; Corbett and Koehler, 2003; Endresen et al., 2003; Dalsøren et al., 2009). Recent trends indicate longer seasons with less sea-ice cover and reduced thickness (Serreze et al., 2007; Boé et al., 2009), implying improved ship accessibility around the margins of the Arctic Basin. Climate models project an acceleration of this trend and opening of new shipping routes and extension of the period during which shipping is feasible (ACIA, 2005; Boé et al., 2009). One set of projections estimate that the navigation season (defined as $25 \%$ open water and $75 \%$ sea-ice cover) for the NSR may increase from the current 70 days per year, to 125 days mid-century, and over 160 days in 2100 (ACIA, 2005, Chapter 16). Ships with ice-breaking capability may extend the navigation season even further. Travel time along the NSR between Europe and the north Pacific Region can be reduced by up to $50 \%$, compared to current sea routes giving large potential transport cost savings (Khon et al., 2010; FNI, 2000). However, the extent to which the NSR is used will depend on a trade-off between reduced travel time and the increased costs and risks of shipping in Arctic conditions.

Recent studies have indicated a large increase in Arctic shipping (Paxian et al., 2010; Corbett et al., 2010; Khon et al., 2010; Granier et al., 2006). Granier et al. (2006) took a scenario from an earlier study (Eyring et al., 2005a) and assumed either $12.5 \%$ or $25 \%$ of the emissions were shifted to the Arctic in 2050 and found that in the summer months surface ozone concentrations in the Arctic could increase by a factor of 2-3. Khon et al. (2010) found that models predict that at the end of this century there will be free passage of the NSR for 3-6 months of the year and the North West Passage (NWP) for 2-4 months. This may make the NSR up to $15 \%$ more profitable than the Suez Canal route (Khon et al., 2010), but they did not estimate future ship traffic in the Arctic. Paxian et al. (2010) estimated present-day and future emission inventories that included polar routes. The ship traffic along the polar routes was estimated using an algorithm that estimated the shortest distance between two ports without included ship performance or cost considerations. They estimated fuel consumption along the NSR and NWP to increase by a factor of 9 and 13, respectively, from 2006 to 2050 (Paxian et al., 2010). Corbett et al. (2010) con- structed detailed inventories of all Arctic shipping activities, including transits of the NSR, NWP and other polar routes with reduced sea-ice extent. Transits were estimated using a fixed percentage diversion of global traffic (1-5\%) and were found to be 2-4 times greater than Paxian et al. (2010) and similar to Granier et al. (2006) (Corbett et al., 2010). In terms of polar transits these studies, however, do not explicitly model ship performance and economic costs of shipping in Arctic conditions.

While the potential for future shipping in the Arctic has been studied, there has been relatively little attention given to future Arctic oil and gas production. With the expected increase in global demand for oil and gas, and decreased in production in certain areas (IEA, 2008), there may be enhanced pressure to expand oil and gas activities in the Arctic. Furthermore, it is reported that over one-fifth of the world's total undiscovered petroleum resources lies north of the Arctic Circle (Gautier et al., 2009). While production in some Arctic oil and gas fields has declined, other discoveries have been made (AMAP, 2010). The Russian Shtokman field in the Barents shelf, one of the world's biggest known offshore gas fields, is currently being considered for development. Despite the potential of the Arctic for future oil and gas production (Gautier et al., 2009), it is not clear that production will increase due to high costs and difficult conditions even with reduced sea-ice (Wood Mackenzie and Fugro Robertson, 2006). Most potential currently remains onshore (Wood Mackenzie and Fugro Robertson, 2006). Together with technology improvements, however, decreased sea-ice extent may increase access allowing further exploration and eventual extraction of oil and gas in the Arctic Ocean.

A basis for this paper is that decreased sea-ice in the future Arctic Region will "unlock" the Arctic Ocean to expanded activities. We develop emission inventories for petroleum and shipping activities in the Arctic for the present (2004) and scenarios for 2030 and 2050. We use a bottom-up engineering model of ship performance in ice conditions to estimate the shipping inventory for transit shipping across the Arctic Ocean. We consider direct routes across the Arctic Ocean in addition to the Northern Sea Route. The use of the North West Passage (NWP) is not considered because channels suited for large ships are likely to continue to have difficult ice conditions for many years ahead (Wilson et al., 2004). For oil and gas production, we use a global model to estimate future activities in the Arctic. A separate inventory estimates the shipping emissions associated with the oil and gas production. As the inventories will be input into chemical transport, radiative forcing, and climate models, they will be determined on a $1 \times 1$ degree grid and cover both short-lived pollutants and ozone pre-cursors $\left(\mathrm{SO}_{2}, \mathrm{NO}_{\mathrm{x}}, \mathrm{CO}, \mathrm{NMVOC}\right.$, $\mathrm{BC}, \mathrm{OC})$ and the long-lived greenhouse gases $\left(\mathrm{CO}_{2}, \mathrm{CH}_{4}\right.$, $\mathrm{N}_{2} \mathrm{O}$ ).

The paper is structured as follows: first, we describe the current activities in the Arctic region with some indications of how they have changed in the past. Second, we describe 
the current and possible future sea-ice extents which make the basis for the activity levels in 2030 and 2050. Third, the majority of the paper will focus on the development of the activity levels for the predicted sea-ice extent and the emission levels based on those activities. The paper will close with a discussion of the results and implications for modelling.

\section{Current Arctic activities}

\subsection{Defining the Arctic region}

The Arctic region has a variety of physical, geographical, and ecological characteristics which may lead to different definitions of the Arctic region. Definitions could extend to the approximate southern boundary of the midnight sun (Arctic Circle, $66^{\circ} 32^{\prime} \mathrm{N}$ ), climate boundaries such as the area north of a given constant mean temperature (isotherm), marine boundaries representing the convergence of different water masses, vegetation boundaries such as the tree line or transition between tundra and boreal forest, and political and administrative considerations. In this article we take an extended version of the definition used by the Arctic Monitoring and Assessment Programme that includes the entire administrative units where a territory is overlapping with the AMAP definition (AMAP, 1998; Glomsrød and Aslaksen, 2009), see Fig. 1. Our focus is on the Arctic Ocean, but we use a broader definition of the Arctic region to fully capture oil and gas activities that may occur onshore (Wood Mackenzie and Fugro Robertson, 2006), but potentially require shipping in the Arctic Ocean.

\subsection{Current oil and gas activities}

Oil and gas activities began in the Arctic region around 1950 (AMAP, 2010; IHS Incorporated, 2009). There was rapid growth in oil and gas production until the collapse of the former Soviet Union in the early 1990s. Oil and gas production dropped to $80 \%$ of peak levels by the mid-1990s and production has now returned to 1990 levels (Figs. 2 and 3). From 1990-2004, Arctic oil production was dominated by West Russia (79\%) followed by Alaska (18\%), Norway (3\%), and small amounts in the other regions. Gas production was also dominated by West Russia (96\%) followed by Alaska (3\%) and small amounts from the other regions. Alaska, particularly Prudhoe Bay, extracts large quantities of gas which are later reinjected as it is too costly to get to market. Around one-half of cumulative Arctic production is oil (51\%), with large regional differences: Canada (59\% oil), Alaska (87\%), East Russia (9\%), West Russia (46\%), and Norway (84\%).

\subsection{Current shipping activities}

An extensive study of present ship activity in the Arctic was undertaken by PAME (2009). The study used 2004 as the

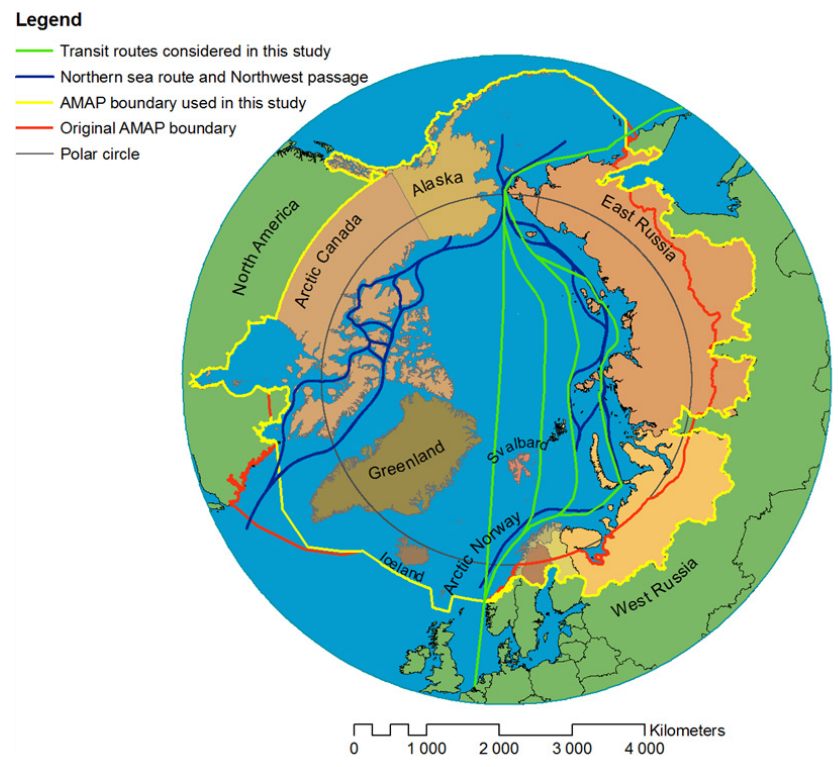

Fig. 1. The Arctic Monitoring and Assessment Programme (AMAP) boundary used in this study compared to the official AMAP boundary. For the oil and gas modelling, the AMAP area is further split into regions: Arctic Canada, Alaska, East and West Russia, Arctic Norway (not including Finland or Sweden), and Greenland.

base year and concluded that shipping activity was dominated by community re-supply, fishing and tourism. Community re-supply is taking place along the NSR and NWP. Excluding ship traffic along the coast of Norway and around Iceland, the bulk cargo is dominated by export from a few large mining operations in Alaska (zinc) and Russia (mainly nickel but also other minerals). Fishing mainly takes place in the ice-free waters around Iceland and in the Bering, Barents and Norwegian Seas, and tourism has its greatest intensity along the coasts of Northern Norway, Southwest Greenland and Svalbard (PAME, 2009). Transport of oil and gas by ships from the Arctic is limited and most of it takes place on the Eurasian side. Commercial transit traffic, except tourism, has taken place only along the NSR, which was opened to foreign ships in 1991 but after 1993 the traffic has been in steady decline. However, 2009 and 2010 saw renewed interest from Western companies to transit the NSR, reducing the journey between Ulsan (Korea) and Rotterdam by 4000 nautical miles $(7400 \mathrm{~km})$.

The estimate of 2004 shipping emissions in the Arctic was based on Dalsøren et al. (2009). Dalsøren et al. used an activity based approach to model global fuel consumption and emissions from all ships above 100 gross tonnes (GT), finding a total fuel consumption of 217 million tonnes (Mt) in 2004. The modelled fuel consumption and corresponding atmospheric emissions were distributed geographically on a $1 \times 1$ degree grid according to the relative number of ship observations in each cell. The ship observation data set used is a 


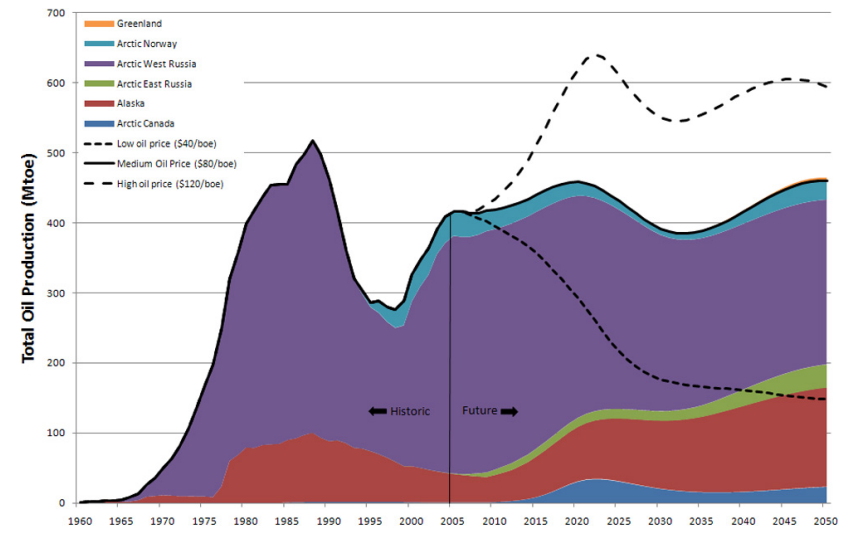

Fig. 2. Historic and estimated oil production in the Arctic with an oil price of $\$ 80 /$ boe (by region) and compared to a low ( $\$ 80 /$ boe) and high $(\$ 80 /$ boe $)$ oil price.

combination of the Comprehensive Ocean-Atmosphere Data Set (COADS) and the Automated Mutual Assistance Vessel Rescue System (AMVER) data with a total of 1990000 ship observations globally. COADS and AMVER data has been used separately by several studies to illustrate global traffic and emissions distributions (e.g., Corbett et al., 1999; Endresen et al., 2003; Eyring et al., 2005b; Beirle et al., 2004) and are considered to be the most comprehensive global ship observation datasets available.

Using the distribution and fuel consumption and emission figures from Dalsøren et al. (2009), and the defined AMAP boundary used in this study (Fig. 1), we find that $6713 \mathrm{Kt}$, or $3.1 \%$ of the global fuel consumption, is located within the AMAP region. We assumed that there was no transit shipping in 2004 and estimated the oil and gas shipping based on the oil tankers operating in the AMAP region $(0.14 \%$ of global oil tankers). We consider that this estimate covers the activities described by PAME (2009).

\section{Future activities in the Arctic}

We now focus on future shipping activities and petroleum production in the Arctic region. While other activities are important in the Arctic (see the Supporting Information for a brief overview), shipping and petroleum production are most related to sea-ice coverage. In our modelling, the future shipping has strong dependence on the future sea-ice conditions. Petroleum production has higher production costs in the Arctic (though the costs are independent of the sea-ice scenarios), but the production locations are partially dependent on sea-ice coverage.

We use several different models in this paper to estimate future activities (2030 and 2050) in the Arctic:

- We estimate the ice coverage using the output of several runs of a climate model and the output is independent of other calculations in the paper

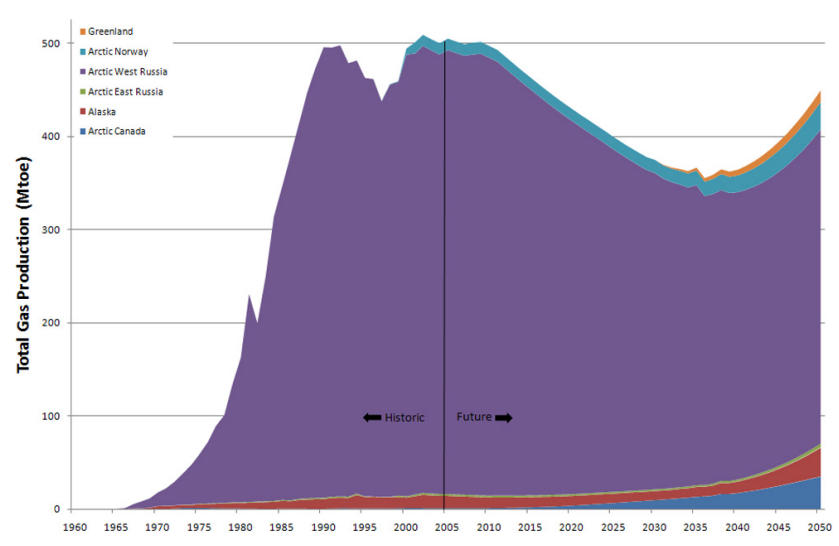

Fig. 3. Historic and estimated gas production in the Arctic.

- Transit shipping is based on an engineering model of ship performance and a cost-benefit analysis to compare alternative transport routes

- Future oil and gas production is based on a model of the global energy markets (FRISBEE)

- The location of the future oil and gas activities is based on the output of the FRISBEE model and location of current Arctic activities, discoveries, exploration areas, and undiscovered reserves

- Oil and gas shipping is based on the output of the FRISBEE model and the engineering model of ship performance

Each of these models are now discussed in turn, starting with the sea-ice scenarios, then the oil and gas production model, and finally the shipping model.

\subsection{Future sea-ice conditions in the Arctic}

Future ice conditions were extracted from the National Center for Atmospheric Research (NCAR) Community Climate System Model (CCSM, Collins et al., 2006). The CCSM3 model was found to be closest to observations between 1972 and 2007 (Overland and Wang, 2007; Stroeve et al., 2007). This model gives a faster reduction of sea-ice cover than the mean of the five models that went into the ACIA assessment (ACIA, 2005, Chapter 16). The CCSM runs are totally independent of other calculations performed in this paper, that is, there is no coupling to the shipping and petroleum models. Ice concentration and ice thickness for four CCSM3 runs were extracted for the years 2007 to 2100 . To avoid random year-to-year variations and produce a smooth development of the future ice conditions a five year running average was used to calculate sea-ice conditions in March, June, September and December (representing each season) in 2030 and 2050. The sea-ice extent was defined as the area where ice 

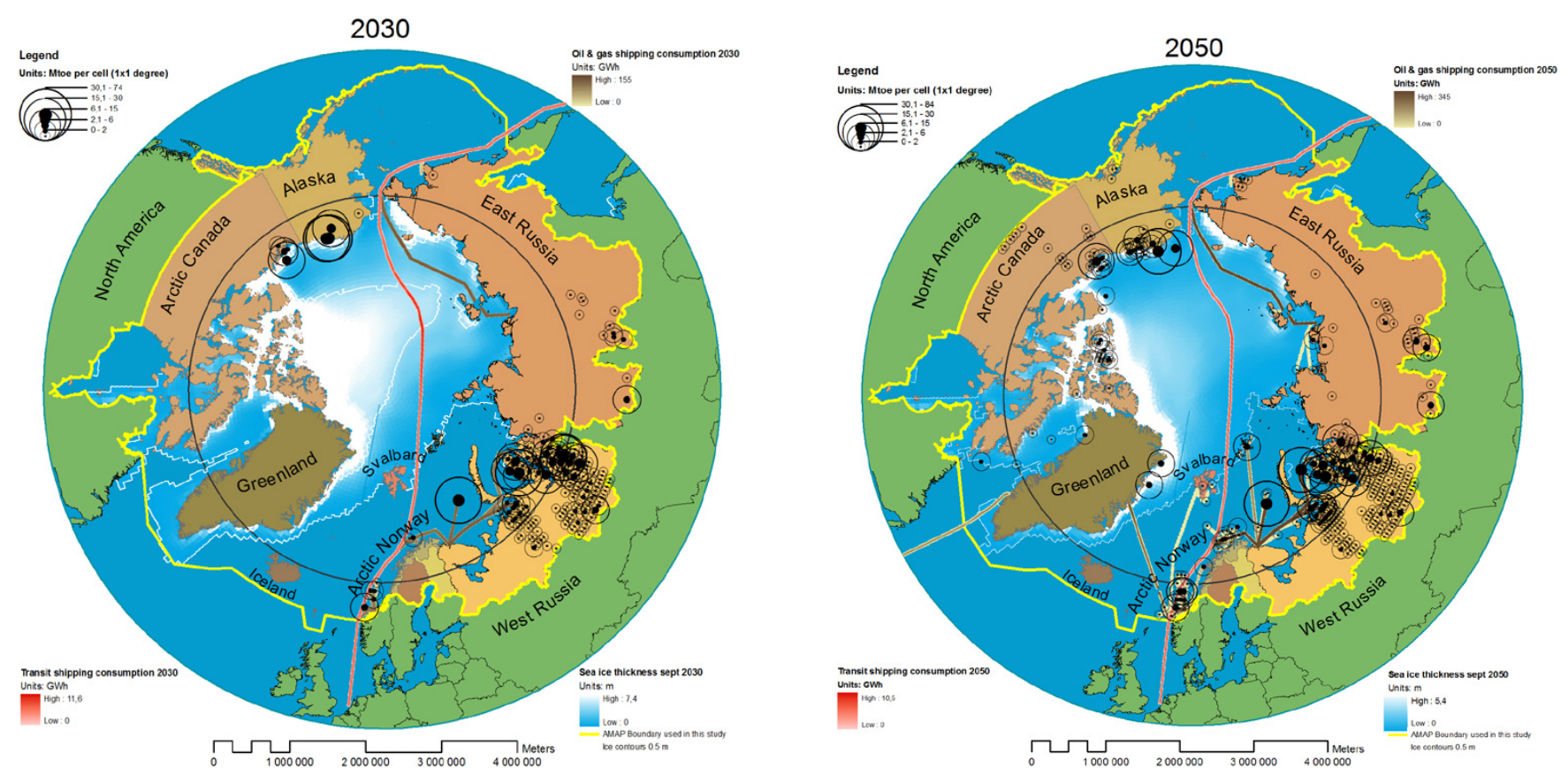

Fig. 4. The oil and gas extraction (measured in Mtoe), energy consumption in transit and petroleum shipping (measured in GWh), and the September sea-ice extent in (a) 2030 and (b) 2050. These data are combined with emission factors to produce the results in respective tables. The transit shipping only occurs during the summer months, while the oil and gas transport occurs throughout the year.

concentration is larger than $15 \%$. The modelled sea-ice extent was translated onto a $1 \times 1$ degree grid, thus ice is removed from all grid cells where the ice concentration is less than $15 \%$. Monthly mean ice conditions were calculated by retaining the correct sea-ice concentration and sea-ice thickness in each cell, while at the same time preserving the total sea-ice area (Eide et al., 2010). The future sea-ice extent in September used in this study for the years 2030 and 2050 is shown in Fig. 4.

\subsection{Future oil and gas production in the Arctic}

Currently, the Arctic produces about a tenth of the world's oil and a quarter of its gas (AMAP, 2008). While some fields are in decline, new discoveries are being made (AMAP, 2010) and there are considerable potential resources in the Arctic (Gautier et al., 2009). The United States Geological Survey (USGS) estimates that the area north of the Arctic Circle contains about $30 \%$ of the world's undiscovered gas and $13 \%$ of the world's undiscovered oil (Gautier et al., 2009) with the largest resources for Russian gas. Despite the large potential, it is not clear whether the Arctic will sustain its current contribution to global supply. To estimate future oil and gas production in the Arctic requires a global model that can estimate the Arctic share of future oil and gas production.

\subsubsection{The FRISBEE oil and gas production model}

The potential scale of future petroleum production in the Arctic region is assessed based on a model of the global energy markets (Aune et al., 2009); Framework of International Strategic Behaviour in Energy and Environment (FRISBEE). The model was previously used for studies of impacts of petroleum industry restructuring (Aune et al., 2005) and globalization of natural gas markets and trade (Aune et al., 2010). A recent working paper provides a detailed description of the application of the model to oil and gas production in the Arctic (Lindholt and Glomsrød, 2011). These publications provide the model details, sensitivity analysis, and a variety of applications. We provide a brief description of the model here and in the Supporting Information, but the reader is encouraged to refer to the references for more specific details.

The FRISBEE model describes future supply and demand of oil and gas through elaborate modelling of oil and gas investments and production. It is a recursively dynamic partial equilibrium model accounting explicitly for discoveries, reserves, field development and production of oil and gas (Aune et al., 2009). The emphasis is on petroleum markets; however, the global market for coal and regional markets for electricity are also modelled albeit in less detail. Production generally takes place in 15 regions and four field categories depending on location onshore/offshore, depth of offshore fields and size of resources (Lindholt and Glomsrød, 2011). 
For each Arctic region, see Fig. 1, the model depicts one field category only. The process of discovering reserves from the pool of undiscovered resources is determined by expected oil or gas prices, field characteristics and the amount of remaining undiscovered resources. The model covers both conventional and unconventional resources. The International Energy Agency (IEA) applies a similar, but more detailed, model structure of the petroleum production and investment decision in their World Energy Model (IEA, 2008).

The current development times and production costs are based on the oil and gas market information (IHS Incorporated, 2009). Future costs and lead times are uncertain, but will probably increase as production moves from onshore to offshore areas, which also often contain smaller fields (cf., IEA, 2008). Exploration and drilling cost are three to five times higher in the Arctic than in other petroleum provinces and thus depending on the oil price production may vary greatly in the Arctic (Wood Mackenzie and Fugro Robertson, 2006). For Arctic regions the time lag from investment decision to maximum plateau production is generally assumed to be $50-100 \%$ longer than in comparable non-Arctic fields, due to lack of infrastructure. Capital and operational costs in new Alaskan fields are assumed to be $50 \%$ higher than average costs of existing fields. For Norway, the costs of new fields are set to $50 \%$ above the cost level of the most expensive field category and Arctic Canada is assumed to have the same costs as Arctic Norway. The cost level in West Arctic Russia is also set to $50 \%$ over existing average cost level for this region, whereas costs in East Arctic Russia are assumed to be twice the existing average cost level, as the infrastructure in the latter area is less developed. Investment costs are assumed to increase over time as the undiscovered resources are being developed.

Arctic and other non-OPEC suppliers respond to the oil price level. The world market price of oil is exogenous in the model and OPEC satisfies the residual demand at the prevailing oil price, determined as the difference between world demand and non-OPEC supply. If demand rises due to income growth OPEC will increase supply to cover additional demand and keep the oil price at the preferred level of the cartel, however, Arctic and other non-OPEC supply remains unaffected as the price is constant. In the gas markets, however, the price is endogenous. The global oil and gas industry outside OPEC is modelled as separate investors allocating a share of the annual cash flow to fields by maximizing net present value of returns. Price expectations are based on adaptive expectations, assuming future prices will equal average of prices over the last six years. The gas price is endogenously determined in regional markets. However the model depicts the gas market as global and integrated, separated by costs of transportation that have declined, in particular for LNG, and tend to harmonize regional prices over time.

At the time of the study, the FRISBEE model did not include activity in Greenland. The production in Greenland was assumed to be zero in 2030 and increase linearly to a value in 2050 that was based on the size of the undiscovered resources (Gautier et al., 2009) and average extraction rates (IHS Incorporated, 2009), see the Supporting Information for more details.

\subsubsection{Oil and gas output from 2000-2050}

Figure 2 shows the future oil production for three oil price scenarios and Fig. 3 shows the future gas production. Figure 2 shows the effects on Arctic oil production when future oil prices (in 2005 USD) rise to $\$ 120$ per barrel oil equivalent (boe) or declines to $\$ 40 /$ boe, which is 50 per cent higher or 50 per cent lower than the oil price reference scenario. Total accumulated oil production is around $27 \%$ higher in the $\$ 120 /$ boe scenario than in the reference scenario. The relative increase in production is higher in Russia than in the other Arctic regions. Total accumulated oil production in the $\$ 40 /$ boe scenario is around $39 \%$ lower than in the reference scenario with similar reductions in relative terms across regions. In either case, even with a high oil price, FRISBEE does not estimate a significant increase in oil production in the Arctic.

Figure 3 shows estimated Arctic petroleum production from 2000 to 2050 with an oil price of $\$ 80 /$ boe. There is a gradual decline in total production until 2030 before a slight increase towards 2050. Production is dominated by West Russia with strong growth in production in Alaska and Canada, and after 2030 in East Russia and Norway. As the price is endogenous in the gas modelling, we do not have different scenarios based on the oil price.

In our modelling of emissions we use the reference scenario ( $\$ 80 / \mathrm{boe})$. In the reference scenario, half of the total accumulated future Arctic production (2000-2050) is oil with large regional differences. Future Arctic oil production as a share of total accumulated production is $67 \%$ for West Russia, $21 \%$ for Alaska, $5 \%$ Norway, and $4 \%$ for Arctic Canada and East Russia. Future cumulative Arctic gas production is $90 \%$ for West Russia, $4 \%$ for Norway, $3 \%$ Alaska, and $2 \%$ for Arctic Canada with smaller amounts in East Russia and Greenland. Over the time period 2000-2050 there is a slight shift of production from gas to oil ( $40 \%$ oil in $2000,51 \%$ in 2050), though the cumulative split is roughly $50 \%$.

Comparisons with other models are found in a separate section below. A recent working paper also provides more details on the analysis of Arctic activities (Lindholt and Glomsrød, 2011).

\subsubsection{Production locations}

The FRISBEE model estimates oil and gas production in 2030 and 2050 for five aggregated Arctic regions: East Russia, West Russia, Alaska, Arctic Canada, and Arctic Norway. We allocate the oil and gas output in these five regions to a $1 \times 1$ grid using field-by-field data on historic oil and 
gas production, estimated resources, and additional data such as stage of production, on/off-shore, and similar data (IHS Incorporated, 2009) and the USGS estimates of undiscovered resources in the Arctic (Gautier et al., 2009). A brief overview of the gridding method is given here, with more details in the Supporting Information.

The gridding is performed in a three step process: first, average cumulative extraction rates are estimated for each field in the database; second, based on the extraction rate and field size, we determine the fields operating in each year; and third, the total extraction in each region estimated using the first and second steps is scaled to match the FRISBEE output. In the first step, the average cumulative extraction rates (cumulative production divided by years in production) for each field are determined using either historic production data or resource size for the fields not currently in production (IHS Incorporated, 2009). In the second step, using information on the current stage of development in each field (IHS Incorporated, 2009), fields are selected that are in operation in either 2030 or 2050. In the third step, the estimated extraction rates in 2030 and 2050 are then scaled so that the regional output matches the FRISBEE model output, that is, steps 1 and 2 are used as gridding proxies for oil and gas production. The USGS data on undiscovered resources (Gautier et al., 2009) are incorporated in the 2050 estimates only. Greenland is not included in the FRISBEE results and the output is estimated using the estimated field size. More details on the gridding are found in the supporting information.

\subsection{Oil and gas emissions}

We use the common Tier 1 approach to constructing emission inventories (IPCC, 2006), based on the relationship Emissions $=$ Emission Factor $\cdot$ Activity. The following sections outline the emission factors, followed by the emission levels under the different scenarios. We focus on climate relevant species (IPCC, 2007b) covering both long-lived greenhouse gases $\left(\mathrm{CO}_{2}, \mathrm{CH}_{4}\right.$, and $\left.\mathrm{N}_{2} \mathrm{O}\right)$ in addition to short-lived pollutants and ozone precursors $\left(\mathrm{SO}_{2}, \mathrm{NO}_{\mathrm{x}}, \mathrm{CO}, \mathrm{NMVOC}, \mathrm{BC}\right.$ and $\mathrm{OC}$ ).

\subsubsection{Emission factors}

The output of the FRISBEE oil and gas production model is measured in the volume of oil and gas extracted at each $1 \times 1$ degree grid point in the Arctic. Thus, the emission factors need to convert the oil and gas output into either energy consumption or directly to emissions. If the former, energy consumption, is chosen then the energy mix and combustion technologies are also needed. Emission factors based on the energy consumption or emissions per unit oil extracted are not widely available. This is most likely since reported emission inventories are usually based on energy consumption by fuel-type, and the energy consumption or emissions from particular activities are not usually grouped together (IPCC,
2006); for example, emissions from gas combustion in a turbine, diesel generators, and fugitive emissions all occur in different parts of a standard emissions inventory.

We estimated the emission factors per unit oil and gas extracted using a variety of different data sources. We took default values from a global dataset based on voluntary reporting by oil and gas companies (Oil and Gas Producers, 2009), but most of these default values were updated using national statistics (see the region-by-region discussion in the Supporting Information). Most national estimates were topdown and obtained by dividing the total oil and gas emissions by the net oil and gas extracted in each region. We used regionally averaged emission factors, corresponding to the five FRISBEE regions, instead of attempting to estimate sitespecific (gridded) emission factors which may vary widely for different fields. We base the emission factors on net oil and gas production (to market) and not gross production to be consistent with the output of the FRISBEE model. We found little variation in the emission factors for oil and gas extraction and for on- and off-shore extraction (Oil and Gas Producers, 2009; Statistics Norway, 2010), consequently, we assume that the emission factor per tonne oil-equivalent is the same for oil and gas extraction and for off- and on-shore facilities.

Table 1 shows the emission factors used for 2004 with further details in the Supporting Information where the data used for each region is explained in more detail. We did not estimate uncertainty ranges for the emission factors, but the long-lived greenhouse gases are the most certain and the BC and OC most uncertain (see Supporting Information). The $\mathrm{BC}$ and $\mathrm{OC}$ estimates were based on shares of PM (Bond et al., 2004). In regions with a high degree of flaring, the emission factors are more uncertain due to lack of data. Despite the potential uncertainties, many of the emission factors are based on top-down estimates, and given the oil and gas output in each region replicate national emissions estimates.

\subsubsection{Aggregated emissions}

Table 2 shows the emission estimates for 2004 calculated using the emission factors in Table 1 and the actual oil and gas production in 2004. As noted earlier, we base the emission factors on the net emissions (oil and gas to market), with the most significant effect for Prudhoe Bay in Alaska where most gas is re-injected due to the high cost of transporting the gas to markets. As our emission factors are partially based on national emission reporting, those emission estimates replicate national emission estimates (see Supporting Information). We have further comparison with another study in a separate section below.

To estimate future oil and gas emissions we multiply the oil and gas output in 2030 and 2050 with the emission factors. It could be expected that the emission factors improve over time with technological development, though, certainly in the case of long-lived GHG emissions, this seems not to 
Table 1. The adopted emission factors per tonne oil equivalent extracted for 2004 (details in Supporting Information). $\mathrm{SO}_{2}$ and $\mathrm{NO}_{\mathrm{x}}$ are based on the molecular weight and not the mass of $\mathrm{S}$ or $\mathrm{N}$.

\begin{tabular}{lcccccccccc}
\hline & $\begin{array}{c}\mathrm{CO}_{2} \\
\left(\mathrm{k} \mathrm{t}^{-1}\right)\end{array}$ & $\begin{array}{c}\mathrm{CH}_{4} \\
\left(\mathrm{~g} \mathrm{t}^{-1}\right)\end{array}$ & $\begin{array}{c}\mathrm{N}_{2} \mathrm{O} \\
\left(\mathrm{g} \mathrm{t}^{-1}\right)\end{array}$ & $\begin{array}{c}\mathrm{NMVOC} \\
\left(\mathrm{g} \mathrm{t}^{-1}\right)\end{array}$ & $\begin{array}{c}\mathrm{SO}_{2} \\
\left(\mathrm{~g} \mathrm{t}^{-1}\right)\end{array}$ & $\begin{array}{c}\mathrm{NO}_{\mathrm{x}} \\
\left(\mathrm{g} \mathrm{t}^{-1}\right)\end{array}$ & $\begin{array}{c}\mathrm{CO} \\
\left(\mathrm{g} \mathrm{t}^{-1}\right)\end{array}$ & $\begin{array}{c}\mathrm{PM}_{10} \\
\left(\mathrm{~g} \mathrm{t}^{-1}\right)\end{array}$ & $\begin{array}{c}\mathrm{BC} \\
\left(\mathrm{g} \mathrm{t}^{-1}\right)\end{array}$ & $\begin{array}{c}\mathrm{OC} \\
\left(\mathrm{g} \mathrm{t}^{-1}\right)\end{array}$ \\
\hline Norway & 58 & 154 & 0.4 & 380 & 1 & 186 & 39 & 4 & 1.1 & 1.2 \\
Russia East & 69 & 620 & 0.5 & 128 & 186 & 121 & 31 & 50 & 15.7 & 17.0 \\
Russia West & 69 & 620 & 0.5 & 128 & 186 & 121 & 31 & 50 & 15.7 & 17.0 \\
Canada & 109 & 110 & 3.3 & 82 & 166 & 331 & 223 & 9 & 2.9 & 3.2 \\
United States & 389 & 1621 & 0.4 & 41 & 23 & 891 & 178 & 97 & 30.5 & 33.1 \\
Greenland & 58 & 154 & 0.4 & 380 & 1 & 186 & 39 & 4 & 1.1 & 1.2 \\
\hline Minimum & 58 & 110 & 0.4 & 41 & 1 & 121 & 31 & 4 & 1 & 1 \\
\hline
\end{tabular}

Table 2. Estimated emissions from oil and gas extraction in the Arctic assuming 2004 emission factors in each year.

\begin{tabular}{|c|c|c|c|c|c|c|c|c|c|c|c|}
\hline \multirow[b]{2}{*}{2004} & \multicolumn{11}{|c|}{ Constant emission factors } \\
\hline & $\begin{array}{l}\text { Oil and gas } \\
\text { (Mtoe) }\end{array}$ & $\begin{array}{l}\mathrm{CO}_{2} \\
\text { (Mt) }\end{array}$ & $\begin{array}{l}\mathrm{CH}_{4} \\
(\mathrm{kt})\end{array}$ & $\begin{array}{c}\mathrm{N}_{2} \mathrm{O} \\
(\mathrm{t})\end{array}$ & $\begin{array}{c}\text { NMVOC } \\
(\mathrm{kt})\end{array}$ & $\begin{array}{l}\mathrm{SO}_{2} \\
(\mathrm{kt})\end{array}$ & $\begin{array}{l}\mathrm{NO}_{\mathrm{x}} \\
(\mathrm{kt})\end{array}$ & $\begin{array}{l}\mathrm{CO} \\
(\mathrm{kt})\end{array}$ & $\begin{array}{l}\mathrm{PM} \\
(\mathrm{kt})\end{array}$ & $\begin{array}{l}\mathrm{BC} \\
(\mathrm{kt})\end{array}$ & $\begin{array}{l}\text { OC } \\
\text { (kt) }\end{array}$ \\
\hline Norway & 46 & 2.6 & 7.0 & 19 & 17 & 0.1 & 8.5 & 1.8 & 0.2 & 0.1 & 0.1 \\
\hline Russia East & 1.5 & 0.1 & 0.9 & 0.7 & 0.2 & 0.3 & 0.2 & 0.0 & 0.1 & 0.0 & 0.0 \\
\hline Russia West & 810 & 56 & 500 & 380 & 100 & 150 & 99 & 25 & 41 & 13 & 14 \\
\hline Canada & 1.8 & 0.2 & 0.2 & 5.9 & 0.1 & 0.3 & 0.6 & 0.4 & 0.0 & 0.0 & 0.0 \\
\hline United States & 62 & 24 & 100 & 25 & 2.5 & 1.4 & 55 & 11 & .0 & 1.9 & 2.0 \\
\hline Greenland & 0.0 & 0.0 & 0.0 & 0.0 & 0.0 & 0.0 & 0.0 & 0.0 & 0.0 & 0.0 & 0.0 \\
\hline Sum & 920 & 83 & 610 & 430 & 120 & 150 & 160 & 38 & 47 & 15 & 16 \\
\hline 2030 & $\begin{array}{l}\text { Oil and gas } \\
\text { (Mtoe) }\end{array}$ & $\begin{array}{l}\mathrm{CO}_{2} \\
\text { (Mt) }\end{array}$ & $\begin{array}{l}\mathrm{CH}_{4} \\
(\mathrm{kt})\end{array}$ & $\begin{array}{c}\mathrm{N}_{2} \mathrm{O} \\
(\mathrm{t})\end{array}$ & $\begin{array}{c}\text { NMVOC } \\
(\mathrm{kt})\end{array}$ & $\begin{array}{l}\mathrm{SO}_{2} \\
(\mathrm{kt})\end{array}$ & $\begin{array}{l}\mathrm{NO}_{\mathrm{x}} \\
(\mathrm{kt})\end{array}$ & $\begin{array}{l}\mathrm{CO} \\
\text { (kt) }\end{array}$ & $\begin{array}{l}\mathrm{PM} \\
(\mathrm{kt})\end{array}$ & $\begin{array}{l}\mathrm{BC} \\
(\mathrm{kt})\end{array}$ & $\begin{array}{l}\mathrm{OC} \\
(\mathrm{kt})\end{array}$ \\
\hline Norw: & 22 & 1. & 3.4 & 94 & 85 & 0.0 & 4.2 & 0.9 & 0.1 & 0.0 & 0.0 \\
\hline Russ & 1 & 1 & & & & & 1 & 0.5 & 8 & 0.2 & 0.3 \\
\hline Russi: & 59 & 4 & 370 & 28 & 1 & 110 & 72 & 8 & 0 & 9.3 & 10 \\
\hline Canada & 30 & 3.3 & 3.3 & 97 & 2.4 & 5.0 & 9.9 & 6.7 & 0.3 & 0.1 & 0.1 \\
\hline United State & 110 & 42 & 170 & 43 & 4.3 & 2.4 & 96 & 19 & 10 & 3.3 & 3.5 \\
\hline Greenland & 0.0 & 0.0 & 0.0 & 0.0 & 0.0 & 0.0 & 0.0 & 0.0 & 0.0 & 0.0 & 0.0 \\
\hline Sum & 77 & 88 & 560 & 440 & 93 & 120 & 180 & 45 & 41 & 13 & 14 \\
\hline 2050 & $\begin{array}{l}\text { Oil and gas } \\
\text { (Mtoe) }\end{array}$ & $\begin{array}{l}\mathrm{CO}_{2} \\
\text { (Mt) }\end{array}$ & $\begin{array}{l}\mathrm{CH}_{4} \\
(\mathrm{kt})\end{array}$ & $\begin{array}{c}\mathrm{N}_{2} \mathrm{O} \\
(\mathrm{t})\end{array}$ & $\begin{array}{c}\text { NMVOC } \\
(\mathrm{kt})\end{array}$ & $\begin{array}{l}\mathrm{SO}_{2} \\
(\mathrm{kt})\end{array}$ & $\begin{array}{c}\mathrm{NO}_{\mathrm{x}} \\
(\mathrm{kt})\end{array}$ & $\begin{array}{l}\mathrm{CO} \\
\text { (kt) }\end{array}$ & $\begin{array}{l}\mathrm{PM} \\
(\mathrm{kt})\end{array}$ & $\begin{array}{l}\mathrm{BC} \\
(\mathrm{kt})\end{array}$ & $\begin{array}{l}\mathrm{OC} \\
(\mathrm{kt})\end{array}$ \\
\hline $\mathrm{N}$ & 56 & 3 & 8. & 2 & 21 & 0.1 & 1 & 2.2 & 0.2 & 0.1 & 0.1 \\
\hline Russia East & 37 & 2.6 & 23 & 18 & 4. & 7.0 & 4.5 & 1.2 & .9 & 0.6 & 0.6 \\
\hline Russia West & 570 & 39 & 360 & 270 & 73 & 110 & 70 & 18 & 29 & 9.0 & 9.7 \\
\hline Canada & 58 & 6.4 & 6.4 & 190 & 4.8 & 9.7 & 19 & 13 & 0.5 & 0.2 & 0.2 \\
\hline United S & 170 & 67 & 280 & 69 & 7.0 & 3.9 & 150 & 31 & 17 & 5.3 & 5.7 \\
\hline Greenland & 17 & 1.0 & 2.6 & 7.2 & 6.5 & 0.0 & 3.2 & 0.7 & 0.1 & 0.0 & 0.0 \\
\hline Sum & 910 & 120 & 680 & 580 & 110 & 130 & 260 & 66 & 48 & 15 & 16 \\
\hline
\end{tabular}

be the case in the oil and gas sector (Oil and Gas Producers, 2009; Statistics Norway, 2010). In the case of longlived GHG emissions, the reason the emission factors vary so little over time is probably a mix of two key factors: first, more energy is required to extract oil and gas as reservoirs become depleted; and second, an increase in flaring will decrease $\mathrm{CH}_{4}$ but increase $\mathrm{CO}_{2}$. Other pollutants that are easier to control, such as NMVOC and $\mathrm{NO}_{\mathrm{x}}$, are more likely to 
Table 3. Estimated emissions from oil and gas extraction in the Arctic assuming 2004 Best Practice emission factors in each year.

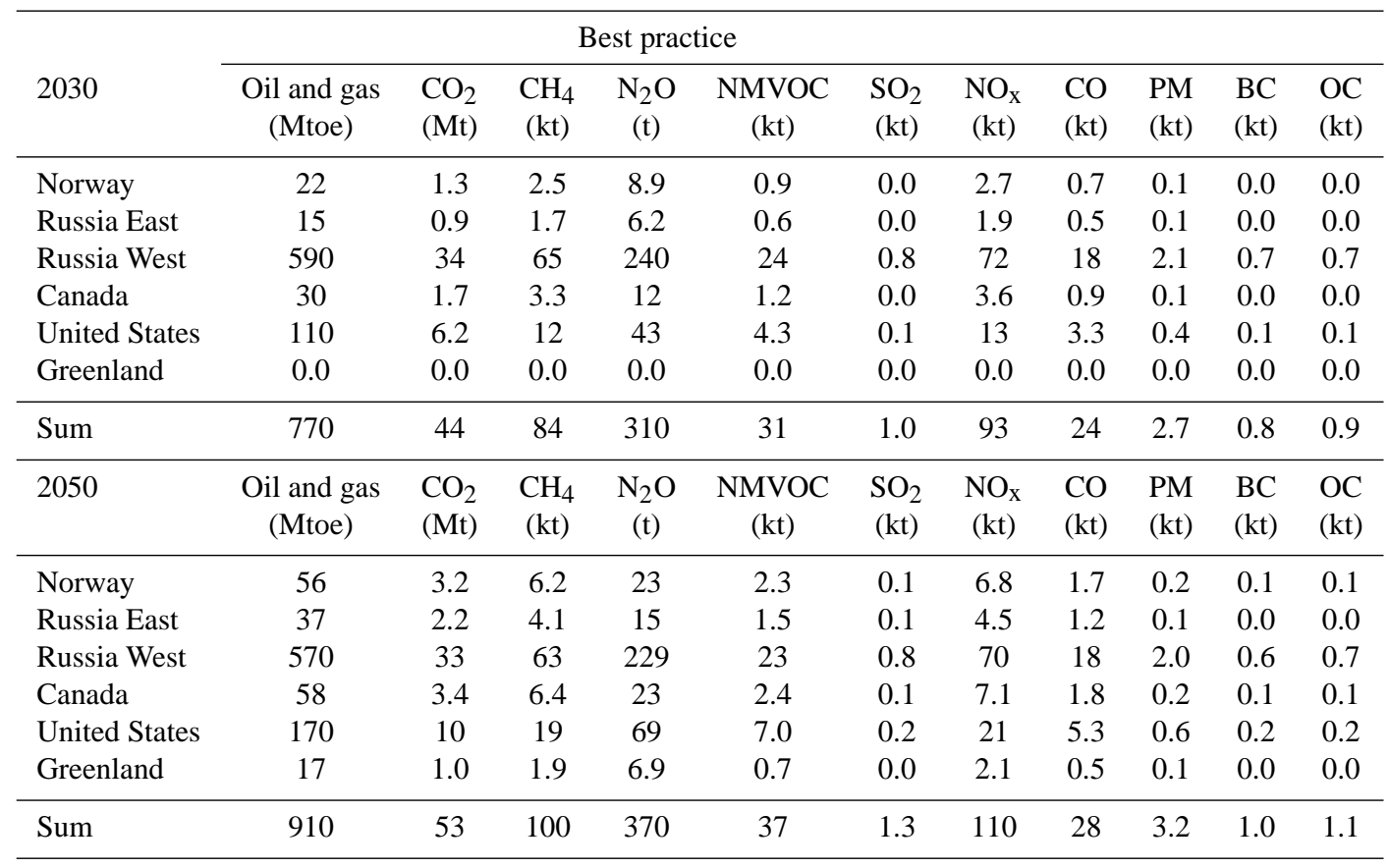

decrease as they are regulated under existing protocols (UNECE, 2005) and mitigation technologies are widely available. A key uncertainty in our analysis is what emission factors to use in 2030 and 2050. Since the data shows little improvement in emission factors over time we use two cases (Tables 2 and 3): first, a case where emission factors are kept constant at 2004 levels ("Constant Emission Factors"); and second, a "Best Practice scenario" where it is assumed that all of the Arctic uses the lowest regional emission factor for each pollutant from 2004. For Greenland in 2050, we assume Norwegian emission factors as newer facilities are likely to use best available technology.

\subsection{Future shipping activity in the Arctic}

\subsubsection{Methodology}

The future Arctic shipping activity has been modelled in two separate segments: transpolar (transit) shipping and shipping related to in-Arctic petroleum extraction. The modelling of both segments relies on an engineering-based model that relates the route choice, ice conditions, and vessel characteristics to fuel consumption for a single voyage. For both segments this single-voyage fuel consumption is combined with an annual activity level (essentially the number of voyages) and emission factors to produce the total segment emission inventories. For transit shipping the number of voyages is determined by a cost-benefit assessment in comparison with traditional routes through the Suez Canal. The Arctic single- voyage fuel consumption serves as input to this cost-benefit assessment, as fuel cost is a major component of voyage costs. For the shipping segment related to petroleum extraction the activity level is not modelled explicitly, but assumed to be proportional to the production data given by the FRISBEE model. Note that there is no feedback mechanism from the petroleum shipping model to the FRISBEE model, and that the transit shipping model is completely independent of FRISBEE.

The per-voyage fuel consumption is calculated by pathintegration of the fuel consumed per unit of distance traversed, which in turn is calculated from modelled ice conditions and ship-specific ice-performance curves. Details on the fuel consumption calculations can be found in the Supporting Information.

For the transit shipping cost-benefit assessment, future Asia-Europe (A-E) traffic across the Arctic is estimated by modelling all A-E cargo flows to be covered by trade between one European port and three Asian ports; Rotterdam - Tokyo (R-T), Rotterdam - Hong Kong (R-HK) and Rotterdam Singapore (R-S). Each port is a representation of a wider geographical area. Future Asia - Europe cargo volumes are estimated by translating the IPCC A2 scenario projections for global economic development into global seaborne trade volumes using the strong historical correlation between Gross Domestic Product (GDP) and seaborne trade, as reported by the EU project QUANTIFY (http://www.ip-quantify.eu) (Endresen et al., 2008). These global projections were then modified for use on the A-E trade. A-E cargo volumes are 
Table 4. Base emission factors in kg emitted per tonne of fuel consumed for an internal combustion engine running on residual fuel oil, as well as emission reduction factors and corresponding emission factors for different pollutants for the years 2030 and 2050 , based on the revised MARPOL 73/78 Annex VI effective as of 1 July 2010.

\begin{tabular}{|c|c|c|c|c|c|c|}
\hline \multirow{2}{*}{ Pollutant } & \multirow{2}{*}{$\begin{array}{l}\text { Base emission } \\
\text { factor }\left[\mathrm{kg} \mathrm{t}^{-1}\right]\end{array}$} & \multirow{2}{*}{ Source } & \multicolumn{2}{|c|}{ Reduction factor } & \multicolumn{2}{|c|}{ Emission factor $\left[\mathrm{kg} \mathrm{t}^{-1}\right]$} \\
\hline & & & 2030 & 2050 & 2030 & 2050 \\
\hline $\mathrm{CO}_{2}$ & 3130 & Buhaug et al. (2009) & 0 & 0 & 3130 & 3130 \\
\hline $\mathrm{CH}_{4}$ & 0.3 & Buhaug et al. (2009) & 0 & 0 & 0.3 & 0.3 \\
\hline $\mathrm{N}_{2} \mathrm{O}$ & 0.08 & Buhaug et al. (2009) & 0 & 0 & 0.08 & 0.08 \\
\hline NMVOC & 2.4 & Buhaug et al. (2009) & 0 & 0 & 2.4 & 2.4 \\
\hline $\mathrm{SO}_{\mathrm{X}}$ & 54 & Buhaug et al. (2009) & $80 \%$ & $80 \%$ & 10.8 & 10.8 \\
\hline $\mathrm{NO}_{\mathrm{x}}$ & 78 & Buhaug et al. (2009) & $3.9 \%$ & $3.3 \%$ & 74.958 & 75.426 \\
\hline $\mathrm{CO}$ & 7.4 & Buhaug et al. (2009) & 0 & 0 & 7.4 & 7.4 \\
\hline PM & 5.3 & Corbett et al. (2010) & $20 \%$ & $20 \%$ & 4.24 & 4.24 \\
\hline $\mathrm{BC}$ & 0.35 & Corbett et al. (2010) & 0 & 0 & 0.35 & 0.35 \\
\hline $\mathrm{OC}$ & 1.07 & Corbett et al. (2010) & $20 \%$ & $20 \%$ & 0.856 & 0.856 \\
\hline
\end{tabular}

Table 5. Fuel consumption and emissions in gigagrams (kilotonnes) of various pollutants as a result of transpolar shipping and oil and gas-related shipping in the Arctic in 2030 and 2050.

\begin{tabular}{ccc}
\hline \multirow{2}{*}{$\begin{array}{c}\text { Pollutant, } \\
\text { short name }\end{array}$} & \multicolumn{2}{c}{ Emissions (kt) } \\
\cline { 2 - 3 } & 2030 & 2050 \\
\hline Fuel consumption & 2880 & 5180 \\
$\mathrm{CO}_{2}$ & 9010 & 16280 \\
$\mathrm{CH}_{4}$ & 0.87 & 1.6 \\
$\mathrm{~N}_{2} \mathrm{O}$ & 0.2 & 0.4 \\
$\mathrm{NMVOC}_{\mathrm{SO}}$ & 6.9 & 12.5 \\
$\mathrm{NO}_{\mathrm{x}}$ & 31 & 55.9 \\
$\mathrm{CO}_{\mathrm{X}}$ & 216.3 & 391 \\
$\mathrm{PM}$ & 21.3 & 38.4 \\
$\mathrm{BC}$ & 12.2 & 22.0 \\
$\mathrm{OC}$ & 1.0 & 1.8 \\
\end{tabular}

split equally between the three hubs, based on current trade statistics for the areas the hubs represent (European Commission, 2010) and assumptions of regional differences in the trade development. The resulting potentials for container traffic between Europe and Asia are 11.7 million Twentyfoot Equivalent Units (TEU) in 2030 and 16.7 million TEU in 2050. For each port pair (R-T, R-HK and R-S) and for each reference year (2030 and 2050) we then compare future voyage costs for Arctic transit against voyage cost for Suez transit. Two alternatives for Arctic transit are investigated; year-round traffic using vessels designed for heavy ice condition, and summer transit using vessels designed for moderate ice. The voyage cost calculations includes fuel costs, explicitly modelling the effect of transiting ice, and additional construction costs for ice-strengthening. For each port pair, cargo volumes are then assigned to the most profitable route, which in turn gives the number of transits in 2030 and 2050. Potential gains from shorter transit times, such as higher freight tariffs, have not been explicitly included in the profitability calculations. However, shorter transit times translates to reduced fleet costs since fewer vessels are required to meet a given transport demand.

We find that part-year Arctic transit will be commercially attractive for container traffic from the Tokyo hub in 2030 and 2050. The predicted amount of containers that will be transported through the Arctic equals 1.4 million TEU in 2030 (36\% of the potential for the Tokyo hub) and 2.5 million TEU in 2050 ( $45 \%$ of the potential for the Tokyo hub). This corresponds to 480 transit voyages, or about $8 \%$ of the total container trade between Asia and Europe, in 2030 and 850 transits voyages, or about $10 \%$ of all container traffic between Asia and Europe, in 2050. The model has been tested with variations in fuel price and length of sailing season, and the conclusions presented are robust with regard to these factors (see Supporting Information). Future work with the model should extend this to include variations in other input factors such as choice of IPCC emission scenario, future ice scenario, ship concept, performance of the vessels in ice, cost of building and operating ice class vessels and alternative logistics, e.g. ice-strengthened vessels just for the Arctic Ocean and cargo transfer ports in the northern parts of the Pacific and Atlantic Oceans.

Shipping activity related to petroleum extraction has been estimated based on projected production data (described in the previous section). The fuel consumed by tanker vessels is modelled by assuming shipping routes and transhipment ports based on the production figures and locations, and by combining this with the same model for fuel consumption as for transpolar shipping. For supply vessels a simplified statistical approach is used to correlate the amount of fuel 
Table 6. A comparison of the emissions from shipping and extraction of oil and gas. The shipping is split between transit, oil and gas, and other activities. The oil and gas covers actual emissions in 2004 and emission based on best practice in 2030 and 2050.

\begin{tabular}{|c|c|c|c|c|c|c|c|c|c|c|c|c|c|}
\hline & & \multicolumn{9}{|c|}{ Shipping } & \multicolumn{3}{|c|}{ Oil and gas } \\
\hline & & \multicolumn{3}{|c|}{ Transit } & \multicolumn{3}{|c|}{ Oil and gas } & \multicolumn{3}{|c|}{ Other } & \multirow{2}{*}{$\frac{2004 \text { actual }}{2004}$} & \multicolumn{2}{|c|}{$2030 / 2050$ best practice } \\
\hline & & 2004 & 2030 & 2050 & 2004 & 2030 & 2050 & 2004 & 2030 & 2050 & & 2030 & 2050 \\
\hline Fuel consumption & $\mathrm{kt}$ & - & 1190 & 1780 & 42 & 1690 & 3400 & 6671 & 6671 & 6671 & & & \\
\hline Carbon dioxide & $\mathrm{CO}_{2}(\mathrm{Mt})$ & - & 3.73 & 5.58 & 0.010 & 5.28 & 10.7 & 20.3 & 20.3 & 20.3 & 82.8 & 44.2 & 52.8 \\
\hline Methane & $\mathrm{CH}_{4}(\mathrm{kt})$ & - & 0.360 & 0.530 & 0.000 & 0.506 & 1.02 & 0.310 & 0.310 & 0.310 & 612 & 84.0 & 100 \\
\hline Nitrous oxide & $\mathrm{N}_{2} \mathrm{O}(\mathrm{t})$ & - & 100 & 140 & 0.257 & 135 & 272 & 496 & 496 & 496 & 434 & 306 & 366 \\
\hline $\begin{array}{l}\text { Non-methane volatile } \\
\text { organic compounds }\end{array}$ & NMVOC (kt) & - & 2.86 & 4.28 & 0.008 & 4.05 & 8.17 & 15.3 & 15.3 & 15.3 & 124 & 31.0 & 37.0 \\
\hline Sulphur oxides & $\mathrm{SO}_{2}(\mathrm{kt})$ & - & 12.8 & 19.2 & 0.170 & 18.2 & 36.7 & 281 & 56.3 & 56.3 & 153 & 1.05 & 1.25 \\
\hline Nitrogen oxides & $\mathrm{NO}_{\mathrm{X}}(\mathrm{kt})$ & - & 89.3 & 134 & 0.176 & 127 & 257 & 491 & 472 & 475 & 163 & 93.0 & 111 \\
\hline Carbon monoxide & $\mathrm{CO}(\mathrm{kt})$ & - & 8.81 & 13.2 & 0.024 & 12.5 & 25.2 & 47.2 & 47.2 & 47.2 & 38.4 & 23.7 & 28.3 \\
\hline Particulate matter & $\mathrm{PM}(\mathrm{kt})$ & - & 5.05 & 7.56 & 0.031 & 7.16 & 14.4 & 48.4 & 38.7 & 38.7 & 46.9 & 2.70 & 3.23 \\
\hline Black carbon & $\mathrm{BC}(\mathrm{kt})$ & - & 0.420 & 0.620 & 0.001 & 0.590 & 1.19 & 1.15 & 1.15 & 1.15 & 14.7 & 0.85 & 1.01 \\
\hline Organic carbon & $\mathrm{OC}(\mathrm{kt})$ & - & 1.02 & 1.53 & 0.002 & 1.44 & 2.91 & 3.87 & 3.10 & 3.10 & 16.0 & 0.92 & 1.10 \\
\hline
\end{tabular}

consumed with the amount of petroleum extracted, using statistics from the Norwegian Continental Shelf (Norwegian Petroleum Directorate, 2010). The results are sensitive to change in input variables such as the estimate of unproven resources, oil price, transportation mode and fluctuating oil and gas markets.

In total, the fuel consumption is 2880 kilotonne in 2030 and 5180 kilotonne in 2050 (Tables 5 and 6), covering transpolar container shipping, supply vessels and tankers transporting petroleum. However, it should be recognized that this study has not covered all Arctic ship emissions, such as from shipping activities related to tourism, local/national transport and fisheries.

\subsubsection{Emission factors}

The emission factors (Table 4) used in this study are based on values of equivalent quantities for slow-speed engines running on residual fuel oil in the Second IMO GHG Study (Buhaug et al., 2009), except for particulates, which we based on Corbett et al. (2010). To allow for changing emissions in the future, due to e.g. international regulations and improvements in technology, we have introduced emission reduction factors. The emission factors improve over time according to a percentage 'reduction factor' relative to the current emission factor based on the regulations of the International Convention for the Prevention of Pollution from Ships, 1973 as modified by the Protocol of 1978 (MARPOL 73/78) which came into effect in May 2005 and the amendments of which came into effect 1 July 2010 (MEPC 176(58)). More details are provided in the Supporting Information.

\subsubsection{Aggregated emissions}

Table 5 shows the fuel consumption and the emissions resulting from transpolar shipping and shipping related to oil and gas-extraction in the Arctic in 2030 and 2050 (a split between petroleum and transit shipping is found in Table 6). These figures include emissions from container vessels on transpolar shipping routes, tankers transporting oil and gas, as well as supply vessels serving offshore installations in the Arctic. As noted earlier, shipping emissions from e.g. tourism, fishing and community resupply are not included in this table.

\section{Comparison with other studies}

An increasing number of studies are appearing on Arctic activities and emissions, though most emphasis has been on shipping. Here we give a brief comparison of our results with other studies.

\subsection{Oil and gas production}

There has been very little academic research on future oil and gas production in the Arctic relative to non-Arctic production. We are aware of one other major study of oil and gas production in the Arctic performed by a private consultancy (Wood Mackenzie and Fugro Robertson, 2006). A direct comparison is difficult as there are differences in geographical definitions and petroleum price assumptions. Wood Mackenzie claims to take profitability into consideration, however, to what extent is not made clear in published material. The petroleum supply from the Arctic region as a whole would, according to Wood Mackenzie, peak around 2030 at 400 Mtoe ( 8 million barrels of oil equivalents per day) with $40 \%$ oil and $60 \%$ gas in the most likely scenarios. In addition, Wood Mackenzie depicts a more optimistic 
scenario for future production where petroleum supply will peak at over 700 Mtoe in 2030 ( $30 \%$ oil and $70 \%$ gas). Our oil reference production level in 2030 is much higher than their most likely level. However, when we apply a low oil price of $\$ 40 /$ boe our production level in 2030 is around 25 percent lower than theirs. Our reference Arctic gas production level in 2030 is close to the average of their reference level of 239 Mtoe and their optimistic level of 483 Mtoe in 2030. Though while differences exist, the results are broadly consistent.

We are not aware of other studies that provide oil and gas output in the Arctic with a high degree of spatial detail $(1 \times 1$ degree grid). Our gridding for 2030 and 2050 is based on current areas of exploration, but many of the undiscovered resources are in or adjacent to existing areas of production (Wood Mackenzie and Fugro Robertson, 2006). For 2050, we use estimated resources which cover large geographic areas (Gautier et al., 2009; IHS Incorporated, 2009) and we visually selected grid points in the USGS Assessment Units which are best for transport or located near other fields. We only place production at realistic and accessible locations (see Supporting Information and Murray, 2006). A consequence of the gridding methodology is that future production locations are potentially more distributed than current production locations (Fig. 4); in reality operators may cluster platforms serving different fields. However, especially in the case of the undiscovered reserves, there is very little information to which to base production locations and consequently locations should be considered to have a high level of uncertainty.

\subsection{Oil and gas emissions}

Our oil and gas estimates for 2004 approximate, where possible, national emissions estimates. In the way of comparison, it is also possible to compare our oil and gas emission estimates with existing global emission inventories that separate out oil and gas production (e.g., EDGARv3.2, Olivier et al., 2005). However, direct comparisons can be misleading since detailed oil and gas platform information is often not used in the gridding of global data sets, and hence emissions may be located further south near population or industrial centres. Over the same AMAP region, the EDGARv3.2 database gives values of $8.0 \mathrm{Mt} \mathrm{CO}_{2}, 6,743 \mathrm{kt} \mathrm{CH}_{4}, 14.5 \mathrm{t}$ $\mathrm{N}_{2} \mathrm{O}, 2,531 \mathrm{kt}$ NMVOC, $72.0 \mathrm{kt} \mathrm{SO}_{2}, 7.2 \mathrm{kt} \mathrm{NO}_{\mathrm{x}}$, and $163 \mathrm{kt}$ $\mathrm{CO}$ (Olivier et al., 2005). The more recent EDGARv4 database has $5.7 \mathrm{Mt} \mathrm{CO}_{2}, 2654 \mathrm{kt} \mathrm{CH}_{4}$, and $45.9 \mathrm{kt} \mathrm{NO}_{\mathrm{x}}$ with the other components not available at the time of comparisons (European Commission, 2009). Except for $\mathrm{CH}_{4}$ and NMVOC, our estimates are larger than other studies and there are two key explanations for this. First, we use bottomup data based on the actual volume of oil and gas extracted and the emission intensities are based on the net volume extracted. In contrast, most global emission data sets, like EDGAR, are based on fuel consumption and averaged emis- sion factors that are not specific to the oil and gas sector. Second, we use detailed gridded data for oil and gas locations. Global datasets often have a mix of gridding proxies which may default to population-based gridding in the absence of more specific data and this may locate the emissions further south around population and industrial centres. In both cases, our approach is more directly related to the activity levels and locations in the oil and gas sector. We have lower estimates for $\mathrm{CH}_{4}$ and NMVOC since we did not estimate leaks from oil and gas transport in our estimates. In the case of BC and OC, Bond et al. (2004) reported estimates of $22.5 \mathrm{kt} \mathrm{BC}$ and $26.3 \mathrm{kt} \mathrm{OC}$ in the entire AMAP region, but this covers all sectors. Thus, it is expected that our estimates will be much lower. Overall, our emission estimates are generally higher than previous estimates, but this could be expected given the more detailed approach we have taken. We are not aware of specific bottom-up estimates of Arctic oil and gas emissions in 2030 or 2050.

\subsection{Transit shipping and emissions}

Several studies have estimated future transit shipping activities and their emissions in the Arctic Ocean. These studies have considered different climate scenarios, regional developments, geo-political issues, ship types, reference year, and output parameters (Ragner, 2000; PAME, 2009; Brunstad et al., 2004; Dalsøren et al., 2007; Verny and Grigentin, 2009; Corbett et al., 2010; Khon et al., 2010; Liu and Kronbak, 2010).

Corbett et al. (2010) and Paxian et al. (2010) are the studies most relevant for comparison with the results presented in this paper. Paxian et al. (2010) give a range of $0.73-1.28 \mathrm{Mt}$ for fuel consumption in the NSR in 2050, which is less than the estimate of $1.78 \mathrm{Mt}$ presented in this study, but of the same order of magnitude. However, their study is not limited to container ships and considers only fuel consumption along the NSR, whereas this study also includes the parts of the journey that lie outside NSR. It seems reasonable to expect that the algorithm employed by Paxian et al. may slightly underestimate Arctic transit traffic since it is based on future projections of historical vessel movements, and since it will only consider vessel movements for eligibility if they travel directly from Asia to Europe.

The estimated $\mathrm{CO}_{2}$ emissions calculated by Corbett et al. (2010) appear to be significantly higher than presented in this study. They give total emissions from all ship traffic in 2030 and 2050, but they have also estimated the proportion that container ships represent of the total traffic. Their estimates of the $\mathrm{CO}_{2}$ emissions from Arctic container traffic in 2030 are 4.8 and $7.7 \mathrm{Mt} \mathrm{CO}_{2}$ for a "business as usual" and high growth scenario, respectively, and for 2050 they estimate 12 and $26 \mathrm{Mt} \mathrm{CO}_{2}$. These numbers are higher than presented in this study by a factor $1.3-2$ in 2030 and 2-4.6 in 2050. The reason seems to be that Corbett et al. (2010) 
estimate that as much as $2 \%$ and $5 \%$ of global seaborne trade will be shifted to the Arctic in 2030 and 2050, respectively.

\section{Discussion}

Our analysis provides emission estimates for oil and gas extraction, and transit and oil and gas shipping in the Arctic region for 2030 and 2050. Table 6, Figs. 4 and 5 show a comparison of the emissions from the extraction of oil and gas, transit shipping, oil and gas shipping, and other shipping activities. The other shipping activities are based on an earlier study using ship observations in 2004 (Sect. 2.3) and in the absence of better data the same activity is assumed in 2030 and 2050. We based the other shipping emissions on the assumed improvements in emission factors (Table 4).

A comparison of the emissions from different activities in the Arctic indicates that emissions will not increase substantially above current levels (Table 6 and Fig. 5), though locations may change (Fig. 4). In 2004 the transit and petroleum shipping emissions were relatively small, requiring rapid growth to reach 2030 and 2050 levels. The rapid growth in the emissions from transit shipping occurs in locations that have not seen substantial emissions before (Fig. 4). However, compared to the business as usual case (no Arctic transit) there is a reduction in global fuel consumption in the shipping sector of $374 \mathrm{kt}$ in 2030 and $932 \mathrm{kt}$ in 2050 as the Arctic transit is shorter than shipping via the Suez Canal. The rapid growth in oil and gas shipping occurs despite relatively constant oil and gas production levels. This is since the sea-ice coverage decreases and new fields are opened in off-shore locations requiring transportation by ship rather than the high levels of pipeline transportation currently in use (Bambulyak and Frantzen, 2009; Dalsøren et al., 2007). In terms of fuel consumption the shipping for oil and gas is around $50 \%$ higher than transit shipping, and other shipping is about twice the oil and gas shipping. In 2030 and 2050, emissions are dominated by petroleum production and other shipping (depending on the pollutant) suggesting relatively modest changes in aggregated emissions driven largely by emission factor improvements. Depending on the pollutant, different activities will dominate future emissions in the Arctic. Petroleum activities have higher emissions from energy use and flaring $\left(\mathrm{CO}_{2}\right.$ and $\left.\mathrm{CH}_{4}\right)$, loading (NMVOC), and estimated particulates. Shipping has much higher emissions of $\mathrm{NO}_{\mathrm{x}}, \mathrm{SO}_{2}, \mathrm{CO}$ and PM. Overall, the emissions are changing in volume, location, and source but we do not find rapid aggregated emission increases in the Arctic region.

Estimating future activities in the Arctic is inherently difficult due to large uncertainties in sea-ice extent, resource availability, future economic development, and future policies. We assume that there are no political instabilities in the region allowing access to all Arctic resources (Brunstad et al., 2004) and we assume continued economic growth at the global level along the lines of the IPCC A2 scenario (Na-

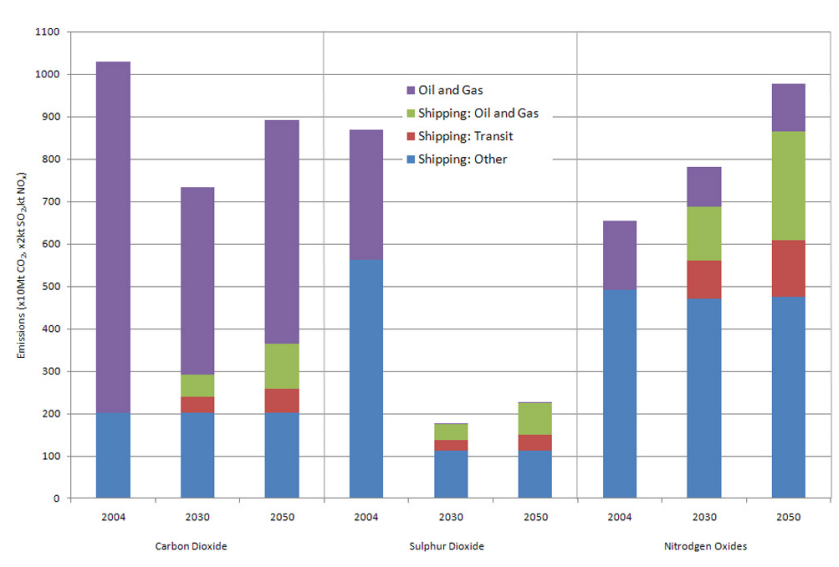

Fig. 5. A comparison of the different emission sources in the Arctic region for $\mathrm{CO}_{2}, \mathrm{SO}_{2}$, and $\mathrm{NO}_{\mathrm{x}}$ (based on the data in Table 6). The "Other Shipping" is not based on calculations performed in the paper. Note the different scales: $\mathrm{CO}_{2}$ is $\times 10 \mathrm{Mt} \mathrm{CO}_{2}, \mathrm{SO}_{2}$ is $\times 2 \mathrm{kt}$

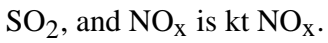

kicenovic and Swart, 2000). We chose a sea-ice model that replicated the recent declines in sea-ice coverage better than other models, though it is unknown if these trends will continue (Boé et al., 2009; Amstrup et al., 2010). Our estimates of oil and gas extraction in the reference scenario are relatively constant seemingly contradicting the potential large increase in extraction based on the significant discovered resources in the Arctic Region (Gautier et al., 2009). However, our reference scenario produces greater oil and gas output than another study (Wood Mackenzie and Fugro Robertson, 2006). In addition to these issues there are considerable uncertainties in technological improvements, emission factors, oil price scenarios, economic growth, and so on. Our results should only be considered as an indication of potential emissions in the Arctic region. Both for oil and gas production and shipping, even with reduced summer sea-ice extent, the Arctic will still be a challenging operating environment and our modelling suggests there will not be a rapid increase in aggregated Arctic emissions up to 2050.

\section{Concluding remarks and further work}

Our analysis has considered future activities and emissions in the Arctic region in 2030 and 2050 on a $1 \times 1$ degree grid and covering both short-lived pollutants and ozone precursors $\left(\mathrm{SO}_{2}, \mathrm{NO}_{\mathrm{x}}, \mathrm{CO}, \mathrm{NMVOC}, \mathrm{BC}, \mathrm{OC}\right)$ and the longlived greenhouse gases $\left(\mathrm{CO}_{2}, \mathrm{CH}_{4}, \mathrm{~N}_{2} \mathrm{O}\right)$. We find rapid growth in transit shipping due to increased profitability with the shorter transit times compensating for increased costs in traversing areas of sea-ice. Oil and gas production remains relatively stable in our scenarios leading to reduced emissions due to emission factor improvements. We find that the location of oil and gas production moves into locations requiring more ship transport relative to pipeline transport, 
leading to rapid growth in emissions from oil and gas transport by ship. Even though we do not find a significant increase in aggregated Arctic emissions, we do find a considerable change in the location of emissions. Studies have found that the forcing and climate response is dependent on the location of emissions and this may partially explain the more rapid recent warming in the Arctic compared to the global average. In future work studies using chemical transport, radiative transfer, and climate models will be used to help understand the forcing and climate response due to emissions occurring in the Arctic compared to those occurring outside of the Arctic.

\section{Supplementary material related to this article is available online at: http://www.atmos-chem-phys.net/11/5305/2011/ acp-11-5305-2011-supplement.pdf.}

Acknowledgements. This work was funded by the Norwegian Research Council (project number: 184873/S30, "Unlocking the Arctic Ocean: The climate impact of increased shipping and petroleum activities (ArcAct)"). We thank Stig Dalsøren (CICERO) for help preparing the 2004 shipping estimates, Øyvind Endresen (DNV) for invaluable discussion and advice on the shipping model, Ole-Christian Ekeberg (DNV) for assistance with the data on sea-ice extent, Øyvind Espeland (DNV) for assistance with shipping in sea-ice conditions, Gjermund Gravir (DNV) for preliminary GIS work, Jonas Karstensen (CICERO) for preparing Figs. 1 and 4, and Terje Berntsen (CICERO and UiO) and Gunnar Myhre (CICERO) for helpful comments. To perform the gridding of the oil and gas production we used gridded data of Arctic oil and gas fields supplied by IHS Inc., its subsidiary and affiliates companies; Petroconsultants S. A.

Edited by: R. Harley

\section{References}

ACIA: Arctic Climate Impact Assessment, Cambridge University Press, 1042 pp., 2005.

AMAP: AMAP Assessment Report: Arctic Pollution Issues, Arctic Monitoring and Assessment Programme (AMAP), Oslo, Norway, 1998.

AMAP: Arctic Oil and Gas 2007, Arctic Monitoring and Assessment Programme (AMAP), Oslo, Norway, 2008.

AMAP: Assessment 2007 - Oil and Gas in the Arctic: Effects and Potential Effects, Arctic Monitoring and Assessment Programme (AMAP), Oslo, Norway, 2010.

Amstrup, S. C., DeWeaver, E. T., Douglas, D. C., Marcot, B. G., Durner, G. M., Bitz, C. M., and Bailey, D. A.: Greenhouse gas mitigation can reduce sea-ice loss and increase polar bear persistence, Nature, 468, 955958, http://www.nature.com/nature/journal/v468/n7326/abs/ nature09653.html\#supplementary-information, 2010.

Aune, F. R., Glomsrød, S., Lindholt, L., and Rosendahl, K. E.: Are high oil prices profitable for OPEC in the long run?, Statistics Norway Discussion Papers 416, Oslo, 2005.
Aune, F. R., Rosendahl, K. E., and Sagen, E. L.: Globalization of Natural Gas Markets - Effects on Prices and Trade patterns, Energy Journal, 30, 39-53, 2009.

Aune, F. R., Mohn, K., Osmundsen, P., and Rosendahl, K. E.: Financial market pressure, tacit collusion and oil price formation, Energy Economics, 32, 389-398, 2010.

Bambulyak, A. and Frantzen, B.: Oil Transport from the Russian part of the Barents Region: Status per January 2009, The Norwegian Barents Secretariat and Akvaplan-niva, Norway, 97, 2009.

Beirle, S., Platt, U., von Glasow, R., Wenig, M., and Wagner, T.: Estimate of nitrogen oxide emissions from shipping by satellite remote sensing, Geophys. Res. Lett., 31, L18102, doi:10.1029/2004g1020312, 2004.

Berntsen, T., Fuglestvedt, J. S., Myhre, G., Stordal, F., and Berglen, T. F.: Abatement of greenhouse gases: Does location matter?, Climatic Change, 74, 377-411, 2006.

Boé, J., Hall, A., and Qu, X.: September sea-ice cover in the Arctic Ocean projected to vanish by 2100 , Nature Geosci., 2, 341-343, 2009.

Bond, T. C., Streets, D. G., Yarber, K. F., Nelson, S. M., Woo, J.-H., and Klimont, Z.: A Technology-Based Global Inventory of Black and Organic Carbon Emissions from Combustion, J. Geophys. Res., 109, D14203, doi:10.1029/2003JD003697, 2004.

Brunstad, B., Magnus, E., Swanson, P., Hønneland, G., and Øverland, I.: Big oil playground, Russian bear preserve or European periphery? The Russian Barents Sea Region towards 2015, Eburon, Delft, 2004.

Buhaug, Ø., Corbett, J. J., Endresen, Ø., Eyring, V., Faber, J., Hanayama, S., Lee, D. S., Lee, D., Lindstad, H., Markowska, A. Z., Mjelde, A., Nelissen, D., Nilsen, J., Pålsson, C., Winebrake, J. J., Wu, W., and Yoshida, K.: Second IMO GHG Study 2009, International Maritime Organization (IMO), 2009.

Collins, W. D., Bitz, C. M., Blackmon, M. L., Bonan, G. B., Bretherton, C. S., Carton, A., Chang, P., Donay, S. C., Hack, J. J., Henderson, T. B., Kiehl, J. T., Large, W. G., Mckenna, D. S., Santer, B. D., and Smith, R. D.: The Community Climate System Model Version 3 (CCSM3), J. Climate, 19, 2122-2143, 2006.

Corbett, J. J., Fischbeck, P. S., and Pandis, S. N.: Global nitrogen and sulfur inventories for oceangoing ships, J. Geophys. Res., 104, 3457-3470, doi:10.1029/1998jd100040, 1999.

Corbett, J. J. and Koehler, H. W.: Update emissions from ocean shipping, J. Geophys. Res.-Atmos., 108, 4650-4666, 2003.

Corbett, J. J., Lack, D. A., Winebrake, J. J., Harder, S., Silberman, J. A., and Gold, M.: Arctic shipping emissions inventories and future scenarios, Atmos. Chem. Phys., 10, 9689-9704, doi:10.5194/acp-10-9689-2010, 2010.

Dalsøren, S. B., Endresen, Ø., Isaksen, I. S. A., Gravir, G., and Sørgård, E.: Environmental impacts of an expected increase in sea transportation, with particular focus on oil and gas scenarios for Norway and northwest Russia, J. Geophys. Res., 112, D02310, doi:10.1029/2005JD006927, 2007.

Dalsøren, S. B., Eide, M. S., Endresen, Ø., Mjelde, A., Gravir, G., and Isaksen, I. S. A.: Update on emissions and environmental impacts from the international fleet of ships: the contribution from major ship types and ports, Atmos. Chem. Phys., 9, 2171-2194, doi:10.5194/acp-9-2171-2009, 2009.

Eide, L. I., Ekeberg, O.-C., Solberg, K. E., and Valkonen, J.: Polarcross 2 - Final Report, 2010. 
Endresen, Ø., Sørgård, E., Sundet, J. K., Dalsøren, S. B., Isaksen, I. S. A., Berglen, T. F., and Gravir, G.: Emission from international sea transportation and environmental impact, J. Geophys. Res., 108, 4560, doi:10.1029/2002JD002898, 2003.

Endresen, Ø., Dalsøren, S., Eide, M., Isaksen, I. S., and Sørgård, E.: The environmental impacts of increased international maritime shipping, past trends and future perspectives, OECD/ITF Global Forum on Transport and Environment in a Globalising World, Guadalajara, Mexico, 2008.

European Commission: Emission Database for Global Atmospheric Research (EDGAR), release version 4.0 (Accessed 29/03/2010), Joint Research Centre (JRC) and Netherlands Environmental Assessment Agency (PBL), 2009.

European Commission: Top Trading Partners - Trade Statistics, 2010.

Eyring, V., Köhler, H. W., Lauer, A., and Lemper, B.: Emissions from international shipping: 2. Impact of future technologies on scenarios until 2050, J. Geophys. Res., 110, D17306, doi:10.1029/2004JD005620, 2005a.

Eyring, V., Köhler, H. W., van Aardenne, J., and Lauer, A.: Emissions from international shipping: 1 . The last 50 years, J. Geophys. Res., 110, D17305, doi:10.1029/2004jd005619, 2005b.

Flanner, M. G., Zender, C. S., Randerson, J. T., and Rasch, P. J.: Present-day climate forcing and response from black carbon in snow, J. Geophys. Res., 112, D11202, doi:10.1029/2006jd008003, 2007.

FNI: Northern Sea Route Cargo Flows and Infrastructure - Present State and Future Potential, Fritjof Nansen Institute, 2000.

Gautier, D. L., Bird, K. J., Charpentier, R. R., Grantz, A., Houseknecht, D. W., Klett, T. R., Moore, T. E., Pitman, J. K., Schenk, C. J., Schuenemeyer, J. H., Sørensen, K., Tennyson, M. E., Valin, Z. C., and Wandrey, C. J.: Assessment of Undiscovered Oil and Gas in the Arctic, Science, 324, 1175-1179, 2009.

Glomsrød, S. and Aslaksen, I. (Eds.): The Economy of the North 2008, Statistics Norway, Oslo, 2009.

Granier, C., Niemeier, U., Jungclaus, J. H., Emmons, L., Hess, P., Lamarque, J.-F., Walters, S., and Brasseur, G. P.: Ozone pollution from future ship traffic in the Arctic northern passages, Geophys. Res. Lett., 33, L13807, doi:10.1029/2006gl026180, 2006.

Hansen, J. and Nazarenko, L.: Soot climate forcing via snow and ice albedos, Proceedings of the National Academy of Sciences of the United States of America, 101, 423-428, doi:10.1073/pnas.2237157100, 2004.

Hansen, J., Sato, M., Ruedy, R., Nazarenko, L., Lacis, A., Schmidt, G. A., Russell, G., Aleinov, I., Bauer, M., Bauer, S., Bell, N., Cairns, B., Canuto, V., Chandler, M., Cheng, Y., Del Genio, A., Faluvegi, G., Fleming, E., Friend, A., Hall, T., Jackman, C., Kelley, M., Kiang, N., Koch, D., Lean, J., Lerner, J., Lo, K., Menon, S., Miller, R., Minnis, P., Novakov, T., Oinas, V., Perlwitz, J., Perlwitz, J., Rind, D., Romanou, A., Shindell, D., Stone, P., Sun, S., Tausnev, N., Thresher, D., Wielicki, B., Wong, T., Yao, M., and Zhang, S.: Efficacy of climate forcings, J. Geophys. Res., 110, D18104, doi:10.1029/2005jd005776, 2005.

IEA: World Energy Outlook 2008, International Energy Agency, 2008.

IHS Incorporated: International Petroleum Exploration and Production Database, IHS Incorporated, Englewood, 2009.

IPCC: IPCC Guidelines for National Greenhouse Gas Inventories, Prepared by the National Greenhouse Gas Inventories Pro- gramme, edited by: Eggleston, H. S., Buendia, L., Miwa, K., Ngara, T., and Tanabe, K., IGES, Japan, 2006.

IPCC: Climate Change 2007: Impacts, Adaptation and Vulnerability. Contribution of Working Group II to the Fourth Assessment Report of the Intergovernmental Panel on Climate Change, edited by: Parry, M. L., Canziani, O. F., Palutikof, J. P., van der Linden, P. J., and Hanson, C. E., Cambridge University Press, Cambridge, United Kingdom, 2007a.

IPCC: Climate Change 2007: The Physical Science Basis. Contribution of Working Group I to the Fourth Assessment Report of the Intergovernmental Panel on Climate Change, edited by: Solomon, S., Qin, D., Manning, M., Chen, Z., Marquis, M., Averyt, K. B., Tignor, M., and Miller, H. L., Cambridge University Press, Cambridge, United Kingdom and New York, NY, USA, 2007b.

Kaufman, D. S., Schneider, D. P., McKay, N. P., Ammann, C. M., Bradley, R. S., Briffa, K. R., Miller, G. H., Otto-Bliesner, B. L., Overpeck, J. T., Vinther, B. M., and Arctic Lakes 2k Project Members: Recent Warming Reverses Long-Term Arctic Cooling, Science, 325, 1236-1239, doi:10.1126/science.1173983, 2009.

Khon, V. C., Mokhov, I. I., Latif, M., Semenov, V. A., and Park, W.: Perspectives of Northern Sea Route and Northwest Passage in the twenty-first century, Climatic Change, 100, 757-768, 2010.

Lindholt, L. and Glomsrød, S.: The role of the Arctic in future global petroleum supply, Statistics Norway Discussion Papers 645, Oslo, 2011.

Liu, M. and Kronbak, J.: The potential economic viability of using the Northern Sea Route (NSR) as an alternative route between Asia and Europe, J. Transport Geography, 18, 434-444, 2010.

Murray, A.: Arctic offers chilly welcome, E\&P, 1 December 2006.

Nakicenovic, N. and Swart, R. (Eds.): Special Report on Emissions Scenarios, Intergovermental Panel on Climate Change, Cambridge University Press, Cambridge, UK, 2000.

Norwegian Petroleum Directorate: Total gross production from the Norwegian Continental Shelf per year, accessed 4 June 2010, 2010.

Oil and Gas Producers: Environmental performance in teh E\&P industry - 2008 data, International Association of Oil \& Gas Producers, Report No: 429, 2009.

Olivier, J. G. J., Aardenne, J. A. v., Dentener, F., Ganzeveld, L., and Peters, J. A. H. W.: Recent trends in global greenhouse gas emissions: regional trends and spatial distribution of key sources, in: Non-CO2 Greenhouse Gases (NCGG-4), edited by: Amstel, A. v., Millpress, Rotterdam, 2005.

Overland, J. E. and Wang, M.: Future regional Arctic Sea ice declines, Geophys. Res. Lett., 34, L17705, doi:10.1029/2007GL030808, 2007.

PAME: Arctic Marine Shipping Assessment 2009 Report, Protection of the Arctic Marine Environment Working Group, Arctic Council, 2009.

Paxian, A., Eyring, V., Beer, W., Sausen, R., and Wright, C.: Present-Day and Future Global Bottum-Up Ship Emission Inventories Including Polar Routes, Environ. Sci. Technol., 44, 13331339, 2010.

Quinn, P. K., Bates, T. S., Baum, E., Doubleday, N., Fiore, A. M., Flanner, M., Fridlind, A., Garrett, T. J., Koch, D., Menon, S., Shindell, D., Stohl, A., and Warren, S. G.: Short-lived pollutants in the Arctic: their climate impact and possible mitigation 
strategies, Atmos. Chem. Phys., 8, 1723-1735, doi:10.5194/acp8-1723-2008, 2008.

Ragner, C. L.: Northern Sea Route Cargo Flows and Infrastructure - Present State and Future Potential, Fridtjof Nansen Institute, 2000.

Rypdal, K., Rive, N., Berntsen, T., Klimont, Z., Mideksa, T., Myhre, G., and Skeie, R. B.: Costs and global impacts of black carbon abatement strategies, Tellus B, 61, 625-641, 2009.

Serreze, M. C., Holland, M. M., and Stroeve, J.: Perspectives on the Arctic's Shrinking Sea-Ice Cover, Science, 315, 1533-1536, doi:10.1126/science.1139426, 2007.

Shindell, D. and Faluvegi, G.: Climate response to regional radiative forcing during the twentieth century, Nature Geosci., 2, 294 300, 2009.

Statistics Norway: Statbank: 03964 Emissions to air, by source and fuel, accessed 26 March 2010, 2010.

Stroeve, J., Holland, M. M., Meier, W., Scambos, T., and Serreze, M.: Arctic sea ice decline: Faster than forecast, Geophys. Res. Lett., 34, L09501, doi:10.1029/2007GL029703, 2007.
UNECE: Protocol to the 1979 convention on Long-Range Transboundary Air Pollution to abate acidification, eutrophication and ground-level ozone, United Nations Economic Commissino for Europe, 2005.

Verny, J. and Grigentin, C.: Container shipping on the Northern Sea Route, International J. Production Economics, 122, 107117, 2009.

Wang, M. and Overland, J. E.: A sea ice free summer Arctic within 30 years?, Geophys. Res. Lett., 36, L07502, doi:10.1029/2009GL037820, 2009.

Wilson, K. J., Falkingham, J., Melling, H., and Abreu, R. D.: Shipping in the Canadian Arctic. Other possible climate change scenarios., IGARSS 2004: Proceedings of the IEEE International Geoscience and Remote Sensing Symposium, 2004.

Wood Mackenzie and Fugro Robertson: Future of the Arctic: A new dawn for exploration (Extended Summary), Wood Mackenzie \& Fugro Robertson, 2006. 